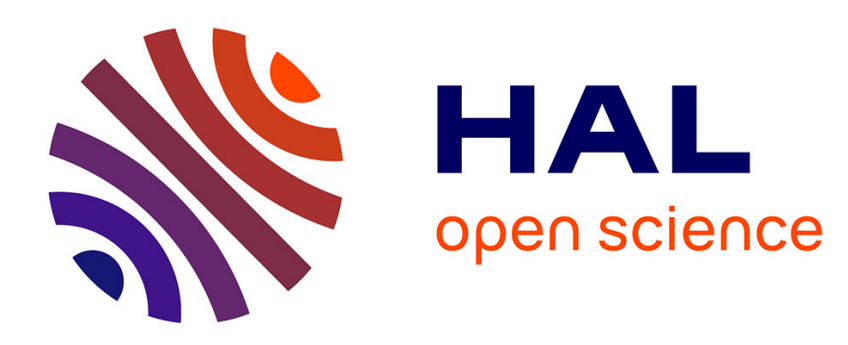

\title{
Visiting History, Witnessing Memory. A study of a Holocaust Exhibition in Paris in 2012
}

\author{
Sarah Gensburger
}

\section{To cite this version:}

Sarah Gensburger. Visiting History, Witnessing Memory. A study of a Holocaust Exhibition in Paris in 2012. Memory Studies, 2019, 12 (6), pp.630-645. halshs-03060656

\section{HAL Id: halshs-03060656 \\ https://shs.hal.science/halshs-03060656}

Submitted on 1 Sep 2021

HAL is a multi-disciplinary open access archive for the deposit and dissemination of scientific research documents, whether they are published or not. The documents may come from teaching and research institutions in France or abroad, or from public or private research centers.
L'archive ouverte pluridisciplinaire HAL, est destinée au dépôt et à la diffusion de documents scientifiques de niveau recherche, publiés ou non, émanant des établissements d'enseignement et de recherche français ou étrangers, des laboratoires publics ou privés. 


\section{Visiting history, witnessing memory: A study of a Holocaust Exhibition in Paris in 2012}

\author{
Sarah Gensburger (translated by \\ Katharine Throssell) \\ French National Center for Scientific Research, France
}

\begin{abstract}
Over the past 20 years, the number of memorial museums and memory exhibitions has increased exponentially and the commemoration of the Holocaust paved the way for this increase. This evolution has given rise to a significant amount of research. However, two questions remain largely unanswered: how are the protocols of memorial exhibitions planned and constructed in concrete terms? And then how do the visitors to these exhibitions use and appropriate this material? The search for the 'visitor's gaze' which is at the heart of contemporary museum studies has only rarely been extended to memorial museums and exhibitions, even those dealing with Holocaust-related topics. This article aims to address this goal. It is thus situated at the crossroads of memory studies and museum studies. Based on extensive empirical material but within the limits of a case study, it focuses on the exhibition C'étaient des enfants. Déportation et sauvetage des enfants juifs à Paris, which was held at the Hotel de Ville in Paris, in 2012. In so doing, it aims to consider some of the underlying assumptions that often go unexamined in the scholarly work on Holocaust memory exhibitions and highlights the centrality of the witnessing memory mechanism as the main way of appropriating the exhibition.
\end{abstract}

\title{
Keywords
}

exhibition, Holocaust, memory, social appropriations, social norms, transmission

\section{Introduction}

Over the past 20 years, the number of memorial museums and memory exhibitions has grown exponentially (Violi, 2012) and the commemoration of the Holocaust has paved the way for this increase (Macdonald, 2013). The expansion is such that in 2001, the International Council of Museums created a Committee of Memorial Museums in Remembrance of the Victims of Public Crimes. These new memory museums differ from the traditional historical ones in the fact that they are not expected to primarily transmit knowledge and traditions of the past, but rather moral lessons, thus participating in the prevention of violence and the construction of social harmony. This evolution has given rise to a significant amount of research. One group of studies has focused on

\section{Corresponding author:}

Sarah Gensburger, French National Center for Scientific Research, Université Paris Nanterre Batiment Max Weber 200 avenue de la République 92000 Nanterre, Paris, France.

Email: sgensburger@yahoo.fr 
the global phenomenon of the emergence of this new category of museums (Williams, 2007). Another group has set out to decode what they display and narrate (Arnold-de Simine, 2013).

Yet these studies reveal, and sometimes explicitly express, two questions that as yet remain largely unanswered (Andermann and Arnold-de Simine, 2012). First, how are the protocols of memorial museums, and the historical exhibitions they most often display, planned and constructed in concrete terms? And second, do the visitors to these museums use and appropriate this material? It is surprising to note that the search for the 'visitor's gaze' (Fyfe and Ross, 1996), what the visitors actually see and how they make sense of it, which is at the heart of contemporary museum studies, has only rarely been extended to memorial museums and historical exhibitions, even those dealing with topics related to the Holocaust. Moreover, with a few notable exceptions, ${ }^{1}$ where they do exist, these studies of visitors' behaviour and practices (of what they do with what they see) in memorial museums are disappointing in this respect (Dartt-Newton, 2011; Dekel, 2009; Lisle, 2006; Popov and Deak, 2015; Arnold-de Simine, 2013). This observation, made nearly 10 years ago by Wulf Kansteiner (2002), remains largely true today. For the most part, these studies 'focus on acts of memorialization, for instance in museum design, assuming the realized object and its meaning is prescribed by its maker's conscious or unconscious objectives' (p. 186).

The need to understand the social appropriations of these apparent vectors of memory is thus one of the main raisons d'être of the recent institutionalisation of memory studies. From its modest position, this article aims to address this goal. ${ }^{2}$ It is thus situated at the crossroads of memory studies and museum studies. Based on extensive empirical material but within the limits of a case study, it looks closely into the social practices of visitors to a Holocaust history exhibition.

This article thus focuses on the exhibition C'étaient des enfants. Déportation et sauvetage des enfants juifs à Paris, which was held at the Hotel de Ville in Paris, in 2012. For 2012, the year of the commemoration of the Vél d'Hiv Roundup, the Mayor of Paris wanted to set up an exhibition. In his words, the exhibition was meant to be 'commemorative', and it was expected to promote 'tolerance' and 'civic education'. In 2011, I was invited to be the curator. I had published several historical books on the persecution of Jews in Paris (Gensburger, 2015; Gensburger and Dreyfus, 2011). However, I was and remain, first and foremost, a sociologist of memory interested in the study of the interactions between memory policies and social appropriations, within a Halbwachsian theoretical framework (Gensburger, 2016a, 2016b). Accepting the curatorship of this exhibition provided a unique opportunity for ethnographic fieldwork based on participant observation. Conducted 'behind the scenes' (Macdonald, 2002), this experience gave rise to the solitary keeping of a field journal, which has since been complemented by research in the city of Paris archives. It forms the first part of the original empirical material on which this article is based. Then, along with colleagues, ${ }^{3}$ we conducted a qualitative study with some of the 120,000 visitors that this exhibition attracted in 3 months. Carried out in autumn 2012, over the course of 3 weeks, this collective research project gave rise to 73 interviews, either individual or in groups, 120 observation sequences and 880 questionnaires. It paid particular attention to visits by school groups since young people are described both by other visitors and by the exhibition's promoters as being the main target audience.

This article begins by exploring the genesis of the exhibition, describing what it was made of and was expected of it. It then turns to focus on the visitors: Who are they? What do they see in the exhibition? What do they make of it? How do visitors acquire historical information? How is it that most of them consider visiting a historical exhibition to be a public memory practice? And, finally, to what extent does the visitors' behaviour highlight some of the legitimate social roles relating to memory of the Holocaust? In addressing some of these questions, this article argues that historical exhibitions, even when given a commemorative function, are not so much a place for the transmission of historical information or moral values, as a place for the acknowledgment of the social 
importance of the very idea of transmission, no matter how effective it actually is. Rather than visiting history, the visitors are first of all witnessing memory and observing both their own and other people's participation in the act of transmission.

\section{Exhibiting Holocaust history: what for?}

\section{Exhibiting history and promoting citizenship}

In France, the state's mobilisation of the past is not new. However, since the beginning of the 1990 s, instead of the national narrative and the tales of great national figures, it has been the commemoration of the sagas of the twentieth century - from World War I (WWI) to the Holocaust that have been the primary material for civic education based on remembrance. In 2012, the Minister for Education permanently institutionalised this connection, creating a 'Memory and Citizenship' correspondent for each school district, responsible for mobilising memory in order to encourage the transmission of the fundamental values of the French Republic. Among the methods that were considered for this transmission, 'educative action in the realm of memory' was particularly encouraged, to be conducted primarily in museums. ${ }^{4}$ These expectations are not limited to the reinforcement of pre-existing shared values but clearly concern the transmission of tolerance and values free from prejudice. One particularly significant example, among many, is the convention signed in February 2016 between the Shoah Memorial in Paris (the main Holocaust museum in France) and the Ministry of Justice. This convention aims to use visits and classes at the memorial as a way of educating, and in a way converting, people convicted for anti-Semitic and racist behaviours and speeches. ${ }^{5}$

The Shoah Memorial has been supported by the City of Paris since its creation in 1953. Indeed, this conviction of the importance of exhibiting memory in order to promote values of tolerance and citizenship is also found in the municipal council in Paris (Image 1). In 2001, the department of the Deputy Mayor responsible for 'Memory' was created, and over the course of its 14 years of existence, the activity of this department has mainly consisted in organising historical and commemorative exhibitions. So far, the majority of these exhibitions have been related to World War II (WWII),

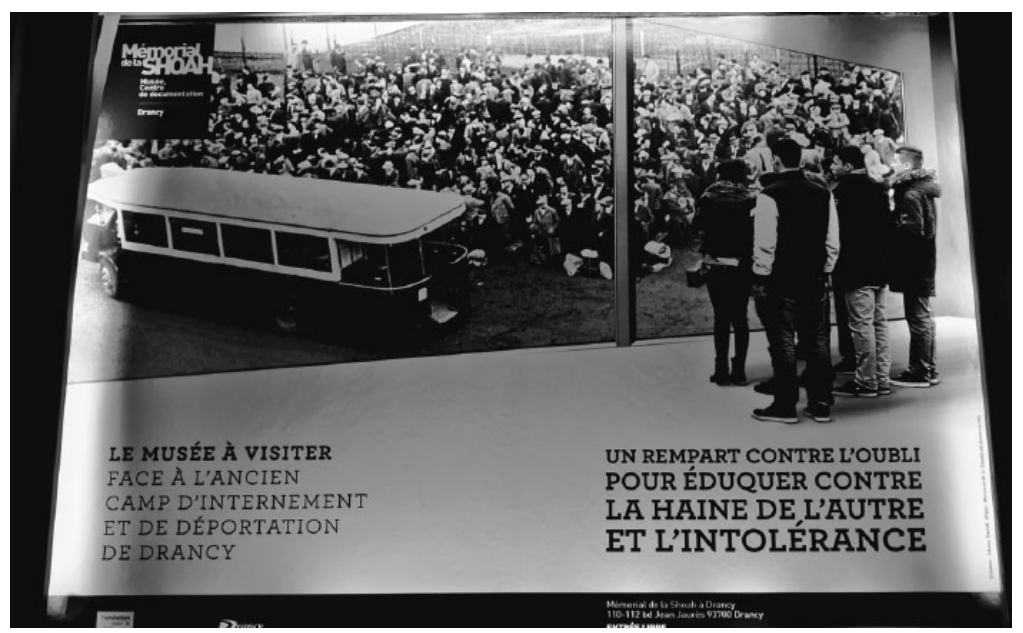

Image I. Advertisement for the Shoah Memorial, Auber train station, RER A in Paris, March 2015. 'The Museum to Visit: a barricade against forgetting, educating against hatred and intolerance'. 
from the Holocaust to the Resistance. Once again, exhibiting the past in such a context has aimed to 'promote republican values', 'progress' and 'tolerance' as stated by the official brochures, as well as by the head of this department during the informal interviews I conducted with her. Most of these municipal exhibitions, which are free, are held in the Hôtel de Ville (Town Hall) itself within a large designated space, composed of four medium-sized rooms.

\section{Authenticity and emotion: the performative power of 'memory'}

In 2011, Catherine Vieu-Charier, Deputy Mayor in charge of 'Memory', along with the then Mayor of Paris, Bertrand Delanoë, decided to organise an exhibition to mark the commemoration of the 70th anniversary of the Vél d'Hiv Roundup, to be held in 2012. As she explained me, this exhibition was not only to 'pay homage to the victims and to the hidden children' but also to 'recall the values of the Republic, to fight against anti-Semitism, and to make an appeal for tolerance'. It became clear through daily interactions that in the minds of the political leaders, the past and its artefacts could speak for themselves. Significantly, the Mayor concluded his preface with these words: 'Let this exhibition be an appeal to faithful memory, to vigilance and to responsibility'.

Ultimately, the conception of the thread of the exhibition, from the writing of the catalogue to the texts produced on the walls, was not subject to any re-reading or verification by the elected representatives or the exhibition services. Indeed, the intended effect of this remembrance was expected to come from the images and objects of the exhibition rather than from the narrative content. As the curator of the exhibition, I thus discussed only these visual supports with the Town Council's team. The first subject of discussion was the decision concerning the photograph to be used for the exhibition poster. The Mayor of Paris had to decide between two proposals drawn up by the Service for Exhibitions. In both projects, the poster presented a black and white image of a group of children. The first was a very clear image of children in the countryside, about to be hidden in non-Jewish families; the photographer was a member of a Jewish rescue network. The historical situation meant that these little refugees had to resemble any other children and that the obligatory yellow stars had to be hidden as well as possible.

The second photograph proposed was a little blurry, a close-up of two children, tired and sad, held in the Drancy transit camp from which they would be deported. Taken by a photographer from the German propaganda service, the yellow stars of these two children are perfectly visible. Image 2 shows the photo that the Mayor chose for the exhibition poster.

This choice sought to privilege what was described by the Mayor and his team as 'historical authenticity', which was supposed to be found in the slightly blurry nature of the image; the sadness of the children liable to give rise to 'emotional responses', referred to by the same people as crucial in the transmission process; and finally, a clearly visible yellow star, which is a key reference in evoking this subject. This choice between two visuals implicitly reveals the kind of magical thinking relative to this exhibition. Moreover, the authenticity of these traces of the past exhibited was expected to qualify the exhibition with a 'museum quality' ('digne d'un musée' in French) in the words of the woman in charge of its concrete realisation working with the Deputy Mayor for 'Memory'. The dramatic nature of these traces, which provoke such emotion, were seen as automatically ensuring memory's power in terms of weakening prejudice and education for tolerance (Hoskins, 2003). However, the exhibition ultimately proved to be a classical history exhibition. It gathered artefacts and photographs, along with descriptive and factual captions and texts. Indeed, with the exception of the Mayor preface and because of my position as a participant observer and as a sociologist of memory, I voluntarily decided not to suggest any explicit moral lesson or civic interpretations at any point. The exhibition was displayed in four different rooms. 


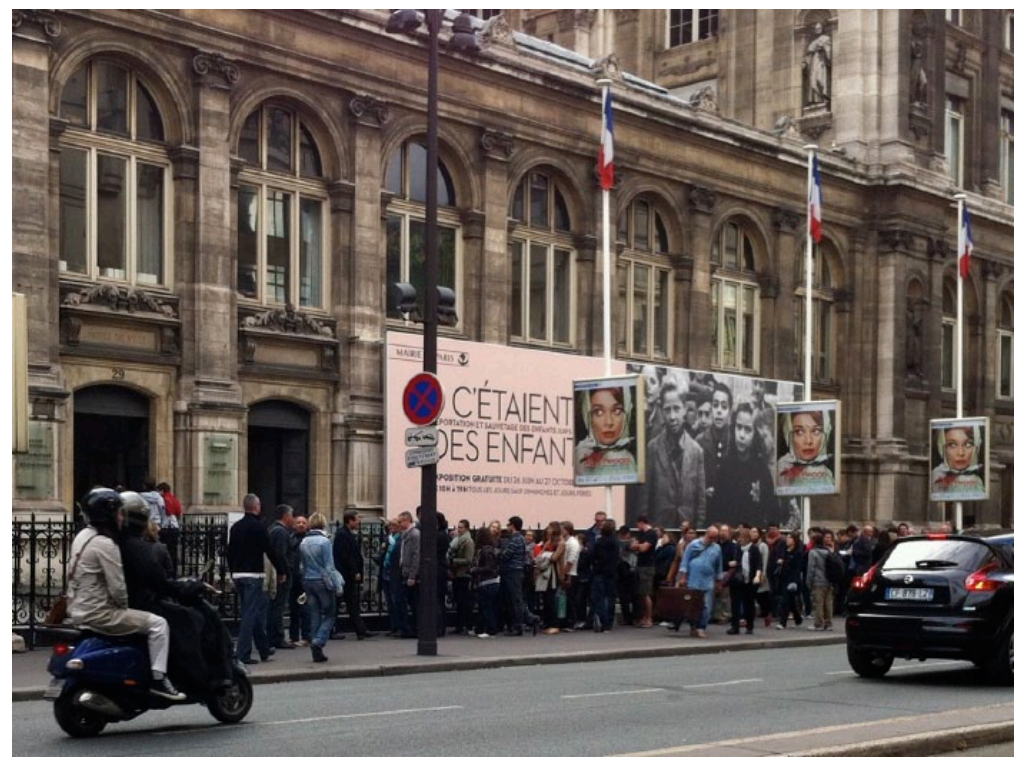

Image 2. Entrance and exhibition poster, Paris Town Hall, October 2012.

The magical thinking of the political promoters of the exhibition is also visible in the way the school public - a target audience if ever there was one - was taken into account in the conception of the exhibition. From the beginning, the commissioners' instructions were that this exhibition should be appropriate for children from age 6 and up. Moreover, in order to encourage class visits, the Paris City Council signed a partnership with the Ligue de l'enseignement, a French association which organises actions with schools in relation to Republican values and civic education. This organisation provided a cultural mediator named Louise, who was responsible for conducting the guided tours with the school groups. I conducted several interviews with her, and 10 out of the 40 class rooms tours she gave were observed, either by me or by other members of the team. In the interviews, as well as in the speeches she gave during the tours that she conducted, the exhibition appeared above all as a structure through which to transmit a civic message, with the material objects considered as intrinsically and univocally the vectors of that message. For instance, Louise repeatedly stated that 'it is very important that many kids come to visit such exhibition'. In response to the question of why school children should visit the exhibition, she said,

If there was a message, I think it would be the acquisition of civic engagement and the fight against discrimination.

\section{What did the Ligue de l'enseignement tell you before you started?}

Well, in fact I became involved after their decision to work with the City Council. And so the tour [for the school students] had already been decided. I was involved only in the visits themselves. But yes civic engagement, they have tours like that, with key words, the importance of remembrance is included in the 'civic engagement' one. It's a good way to do it, because it gives rise to a feeling of injustice [in children's minds] and when we see, when we feel these things, we will try to confront them and to get interested in discriminations and fight against them. 


\section{Who visits Holocaust history?}

This civic expectation supposes that the visitors are, at least partly, diverse in their sociological characteristics. But who visited this exhibition? And what did they actually see in what was exhibited?

\section{All visitors? All citizens?}

We administered 880 questionnaires over the course of 3 weeks in October 2012. We covered every single individual visitor (schools visits were not included), for 1 hour a day, changing the given hour every day. These data give us some information not only about what the visitors thought of the exhibition but also about who they were. If part of the literature on Holocaust memory insists on its globalisation (Levy and Sznaider, 2002), the audience of this memory exhibition does not represent the global population of Paris. It does not depart in any way from the social stratification that structures museum visits in France overall (Credoc, 2012). First, far from the idealised image of a young audience - these citizens of the future to be educated through the lessons of the past the visitors were not young. At the time of their visit, $49 \%$ were over 50 years old and $29 \%$ were retired. They were also educated and belonged to higher social categories: $53 \%$ had at least 4 years of post-secondary education. Among the visitors who were not yet retired, only $1.8 \%$ were working class; inversely, 34\% were managers or senior intellectual professionals. Finally, a large number were 'expert visitors' (Davallon et al., 2000), with 80\% attending more than one historical exhibition a year, $37 \%$ more than three, $45 \%$ saying they were passionate about history and $40 \%$ saying they were particularly interested in the history of WWII.

The social stratification of the public does not stop there. For clear legal and ethical reasons, ${ }^{6}$ the questionnaires did not include any questions on ethnic origin or religion. However, we also conducted 73 interviews. Each time, we tried to vary the social characteristics of the visitors we spoke to. We paid particular attention to vary the age range, the gender and the ethnicity. If the qualitative study conducted through interviews has no statistical value, it still provides some complementary data in this area. On one hand, among the visitors living in France as permanent residents, who had come individually (as opposed to students in schools visits), visitors born overseas and visible minorities are two categories that were almost non-existent among the visitors. On the other hand, nearly half of the people we approached for an interview at the end of their visit to the exhibition spontaneously declared that they or an immediate family member were Jewish. The exhibition therefore seems not to have had a large power of attraction. It clearly did not reach everyone; or rather, it specifically reached some and not others. The civic message liable to be transmitted, therefore, only really reaches categories of the population who are already sociologically inclined to actively participate in democratic life, on one hand (Fyfe, 2006), and who are already interested in the history of the Holocaust and inclined to be less prejudiced than most, at least as far as anti-semitism is concerned, on the other. In this respect, the very large number of visitors of C'étaient des enfants $(120,000)$ compared to the average observed in other similar Parisian institutions (Eidelman et al., 2012) should not be interpreted as a sign of the diffusion of the memory of the Holocaust within the French society as a whole.

We will now focus on a specific group of visitors, who happen to be the target audience of the exhibition. Who are these school children who are brought to this exhibition in the hope that it will contribute to their civic education? The Town Hall is situated in the centre of Paris. It is equally accessible to all Parisian schools. Forty classes from the final years of primary school (covering children who are roughly 9-10years old) visited the exhibition through the mediation programme proposed by the Ligue de l'enseignement. Their geographic distribution can be seen on the map below. 


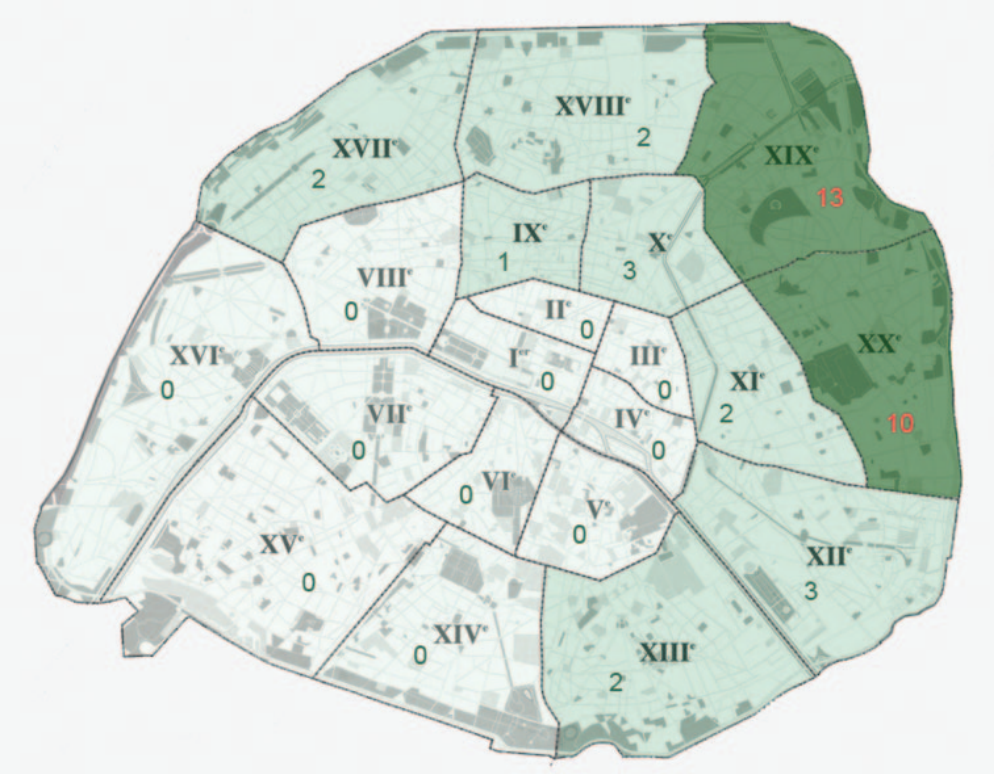

Map. Distribution by district of the 40 school classes that attended the exhibition.

(c) Clara Gensburger.

These students attend schools that are all almost exclusively located in the East of Paris. This geographical distribution corresponds to specific social characteristics that are radically different from those of the visitors who come voluntarily. These districts have high levels of poverty and the highest concentrations of immigrant families - particularly from sub-Saharan and North Africa - in the capital. The 19th district for example, which had the greatest number of classes attending the exhibition, also has the highest measures on these two indicators. Moreover, even from within the more advantaged districts, it was predominantly the more disadvantaged schools that decided to bring their classes to the exhibition. In fact, two-thirds of the classes accompanied by the Ligue de l'enseignement were from 'priority education zones', the label that the education system gives to schools in which students face numerous simultaneous social difficulties, such as poverty and recent migration of their parents. The differences between the profiles of the voluntary visitors and the school visitors are striking. This would suggest that school visits to see the history of the Holocaust history are apparently intended for some children more than others, possibly participating in typifying this kind of student as citizens to be or at least to be perfected.

\section{Is the exhibition about the past?}

Once we have identified the objective characteristics of visitors, however, the question remains, for those who do attend, what does a visit to a Holocaust history exhibition signify in subjective terms? We chose not to use a questionnaire on historical knowledge in order to identify the social appropriations that the exhibition may be the object of (Mance and Savoie, 2011; McRainey and Russick, 2010). On one hand, studies conducted with knowledge-based questionnaires implicitly assume that the increased knowledge of the past (which is the object of the measure) will effectively enable the civic transformation expected and attest to the transmission process (Lawrence, 1991). On the other hand, they reduce the experience of the visit to the historical dimension of the exhibition. Yet, 
qualifying these exhibitions as historical, or even memorial, is not straightforward if we are interested in how the visitors understand them. Here, we are defending the relevance of an alternative position: not assuming the 'historical' or 'memorial' nature of such a visit per se. Instead, we ask, what meanings and status do people give to their practices of visiting such an exhibition?

We conducted an in-depth ethnographic study of the visitors. We realised two types of observation sequences. First, whenever possible, we interviewed people as they left the exhibition, after having previously observed them during their visits. Second, we selected some parts of the exhibitions, such as the preface, the Vél d'Hiv display and other parts of the scenography. During the interviews, we asked the visitors, as an open question, whether or not this was the first time they had come here. From there, we tried to encourage them to speak about what they thought of the exhibition, which parts they found interesting, moving or shocking, and so on. The interview was not meant to assess what they had retained but what sense they gave to their visit and to what they had seen, and how they put these experiences into words.

As the literature on social appropriation of arts or science exhibitions has already acknowledged, within this exhibition, what is seen in this exhibition makes sense according to a mechanism of recognition. A particular visual or piece of information is appropriated because it is recognised (Thomas, 2009). Indeed, almost all the visitors began the interview by explaining that although the exhibition was 'very successful', they 'didn't learn anything new' because they already knew 'this history'. 'I know this story by heart' said one visitor in his 20 s, 'we know this story' said a pair of American tourists in their 50s, even before we could ask them the first question. Although this affirmation is of course almost inevitable - in 2012 in Paris, it is probably impossible to admit to just discovering the deportation of Jewish children - it also demonstrates the fact that the visualisation of the past is part of a cultural system that forms a screen through which the exhibition is seen and within which it is meaningful. Yet, the contours of this system are very broad. Well beyond the self-referencing of the past by the past, these contours sketch the space of cultural capital as a whole and, beyond that, ordinary daily life.

The interviews systematically revealed that the frame of perception of the exhibition first extends to a range of cultural references linked to the historical period. The display case on the history of the Vél d'Hiv Roundup was thus regularly mentioned in the interviews as something meaningful to the visitor - often not explicitly but constantly implied by the systematic reference to a film called La Rafle (The Roundup). This film was aired for the first time on French television on 15 October, right in the middle of our fieldwork, with a national audience share of $28 \%$. Three million people had already seen it at the cinema. Out of the 73 visitors we interviewed, 15 recognised this as a well-known theme. From this prior knowledge, it was possible for them to discover more. For example, some of the people interviewed shared their discovery of one aspect of the Holocaust that they did not know about: the life of the children after the war, the number of orphans and the establishment of Jewish Children's Homes. They all specified on this occasion that 'it wasn't mentioned at all in La Rafle'. Here, the viewing of the film provided a frame for the appropriation of the exhibition, and a filter for the encounters with the artefacts on display. According to a mechanism similar to the 'tourist gaze' documented by John Urry (2002), the visitors' experience is framed and structured by a pre-existing familiarity.

The observation of the importance of the global cultural system and the recognition process does not however prove the existence of a 'visual collective memory' (Brink, 2000). Although images and traces of the past are appropriated as part of a system of cultural significations, this occurs in different ways (Crane, 1997). Yet, this diversification does not solely, or even principally, take place according to the past 'transmitted' or the 'history lived personally', as is often assumed. People see history, even when related to familial memory, through appropriations of material. In the interviews, the reference to some objects was far from systematic (20 of 73 ). In most of the 
case, the visitor did not feel like describing an artefact of the exhibition that had meant something to him. But when he or she did, the objects referred to were systematically associated with their contemporary daily life. We will take one example here. The display case on the Drancy ${ }^{7}$ internment camp contained a collection of paper dolls made by young detainees. One woman took the initiative to come and speak to us. She immediately declared,

I liked this exhibition very much. It was interesting because my uncle was deported to Buchenwald Dora and I am a member of the association Buchenwald Dora. But I actually wanted to say that I collect paper dolls and that display was fascinating for me. I'd love to be able to photograph those little dolls, if you could help me. ${ }^{8}$

In the same sequence emerges what should be seen (the history of deportation) and what is actually seen (the paper dolls). This mechanism is well known to the researchers who study the social appropriations of exhibitions (mainly of art or science), but it has not been highlighted in the case of Holocaust, nor for historical exhibitions more generally. Here, as elsewhere, an ordinary prism allows the visitor to see the extraordinary.

Moreover, a visit to this kind of exhibition, like any other, is framed by the social situation in which it takes place. On this point, our observations of 10 school visits are particularly revealing. In these cases, two of us followed the group and took note of the interactions. At the end, we had informal discussions with the students. A pattern clearly appeared. The children experienced the exhibition mainly as students and their social status strongly framed the appropriations of the exhibitions.

On the day Image 3 was taken, the children were almost exclusively interested in the documents that bore the mark of the lives of these Jewish children as school students in Paris. They were systematically drawn to school books and drawings. For these particular artefacts, the young visitors engaged closely with the materiality of the documents. They carefully read a letter written in a child's hand, to admire the beautiful handwriting and check the spelling. The hunt for mistakes was thus a frequent activity for the children visiting with their classes. In front of the display of artwork, they marvelled at the colours and papers, the constructions and collages. Visiting the history and artefacts of the Holocaust was for them here, first and foremost, an activity associated with school.

This effect of the school as a filter, as a social frame in which the experience of the visit is inscribed, is particularly apparent if we compare these school visits with children attending with their families. In the latter case, the children are not much interested in the documents and objects connected to school, and prefer the displays concerning the separation of the children from their parents or which contain family photographs. This observation gives us an idea of the complex mechanism through which the authenticity impacts upon the visitor and more broadly the way the visits are framed as social practices. Here, we concur with the conclusions made by Siân Jones (2010), on very different ethnographic material and on a complete different kind of exhibition: 'when we look at how people experience and negotiate authenticity through objects, it is the networks of relationships between people, places and things that appear to be central, not the things in themselves' (p. 181).

\section{Visiting history, witnessing memory}

We have at this point an assessment of who attended this exhibition and of some of the mechanisms through which the visitors engaged with the materials on display. It is now possible to address the issue of the 'transmission of values' which is at the core of the political expectations but also present in the scholarly literature linking human rights and memory (Levy and Sznaider, 2010). The 


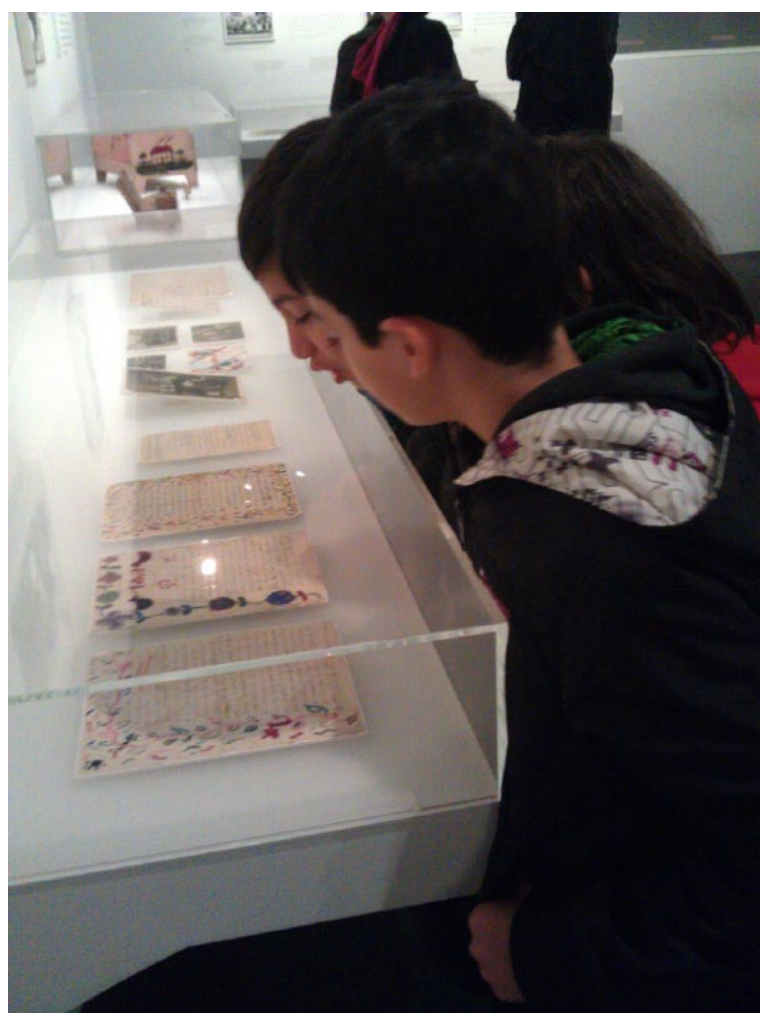

Image 3. Visit of a class from the 18th district, 16 October 2012.

'There aren't many spelling mistakes, you see? They wrote well'.

issue of values in museums is not new but has not given way to studies of their actual appropriations (Huistra and al, 2014; Jonsson, 2012). As was said previously, few of the visitors ultimately make reference to particular artefacts of the exhibition, and the historical narrations in themselves are rarely assimilated. However, the values that this exhibition is intended to convey are indeed and abundantly - cited: the emotion, the 'importance of memory', the 'never again', the fight against racism and anti-Semitism, tolerance and equality, the defence of the Republic and democracy. In other words, rather than the transmission of historical information and civic values, visiting history enables the witnessing of the very process of transmission, for oneself but most of all for 'others'. The social effect of the exhibition relies first on the fact that the visitors observe each other and, in doing so, mutually reinforce the social value of the lessons that they are intended to draw from this Holocaust history exhibition.

\section{Social appropriations and civic values}

As stated above, the only text in the exhibition that explicitly addressed the civic lessons that should be taken from this visit was the preface by the Mayor of Paris. Of the $40 \%$ of visitors who read the preface, $70 \%$ were women. It was therefore women who were the most exposed to this discourse, yet in the interviews (again conducted alternatively with women and men), it was overwhelmingly the men who situated the experience of their visit in the context of the civic lessons of history, most often referring to the 'importance' and the 'lessons of memory'. Inversely, the women 
remained more at the level of sensory experience and emotions in their comments, sometimes not hesitating to refer to a specific object that was particularly meaningful for them. This type of concrete material reference to the exhibition was absent from interviews with men. This example invites us to dissociate the visit experience and the expression of values and to look beyond the 'transmission' paradigm to understand what is at work here. In other words, it appears that the visitors entered into the exhibition space with a system of values already in place, of which the public expression is (unsurprisingly) heavily gendered. Rather than an actual transmission of historical knowledge and social values, the experience of the visit enables the social and sometimes public actualisation of the values that pre-existed it. Here, the mechanism is one of reinforcement and legitimation. Once again, the observation of class visits provides a magnifying glass through which to examine this mechanism.

From the very start of their visits, the school groups were most often vocal in expressing their opposition to racial prejudice and discrimination. In the first room of the exhibition as soon as Louise mentioned that in Paris all Jews over 6 years old were obligated to wear the yellow star, children exclaimed, 'that is really racist', 'that isn't fair, it's discrimination', 'but that's not right! They should have told the police' and so forth. This is an example of an exchange between Louise and two young boys from a CM2 class:

Young boy 1: Why did they wear the star? They should have refused.

Young boy 2: What I don't understand is why the parents were deported before the children.

Louise: $\quad$ To avoid the reaction of public opinion, to manipulate people.

Young boy 2: But why didn't the people who saw the massacres revolt? Didn't they say anything?

The reactions of the children indicate that the values - tolerance and indignation when faced with discriminations - are already strongly established. The children arrive bearing in them these values that are staged in the exhibition space. Here, the observation is identical to that made by Rachel Hughes (2008) in her enlightening study on the visits to the Tuol Sleng Museum of Genocide Crimes in Phnom Penh. In her case, visiting Cambodian Genocide history was not so much a practice of dark tourism (the content and the artefacts on display were not so important) as a way for the visitors to publicly acknowledge their sharing of humanitarian values and concerns. In the same way, it leads us to pay attention not only to the interpretative dimension of the visit but also to its symbolic nature. These school children who voice their indignation so spontaneously (their 'sincerity' is not questioned here) are complying to a social role, as Erving Goffman defines it, and responding to the symbolic status of the exhibition. Attending such an exhibition means publically displaying one's respect for a certain number of values that it is designed to transmit. In return, this collective actualisation, and the fact that others are witnessing it, may reinforce their internalisation of these values. The process at work here is in fact one of actualising pre-existing, universalist, values in shared space and based on sensory materials appropriated through the prism of daily life. Echoing the concept of cultural intimacy developed by Michael Herzfeld (2005), this mechanism could be called intimate universalism.

In the interviews, visiting an exhibition on the history of the Holocaust is clearly referred to by the visitors as a 'memory' practice. Moreover, this memory appears not primarily as a vector for the spread of values, but as a value in itself, of which the relevance needs to be continually re-affirmed. If exhibiting Holocaust history works in this sense, it is because it participates in legitimising the social importance of memory (rather than the values or the narratives in themselves). Peter A. Meyers, reviewing Peter Novick's book on The Holocaust in American Life, alluded to this 'commonplace' mechanism which gives Holocaust Memory most of its actual social impact (Meyer, 2002). 


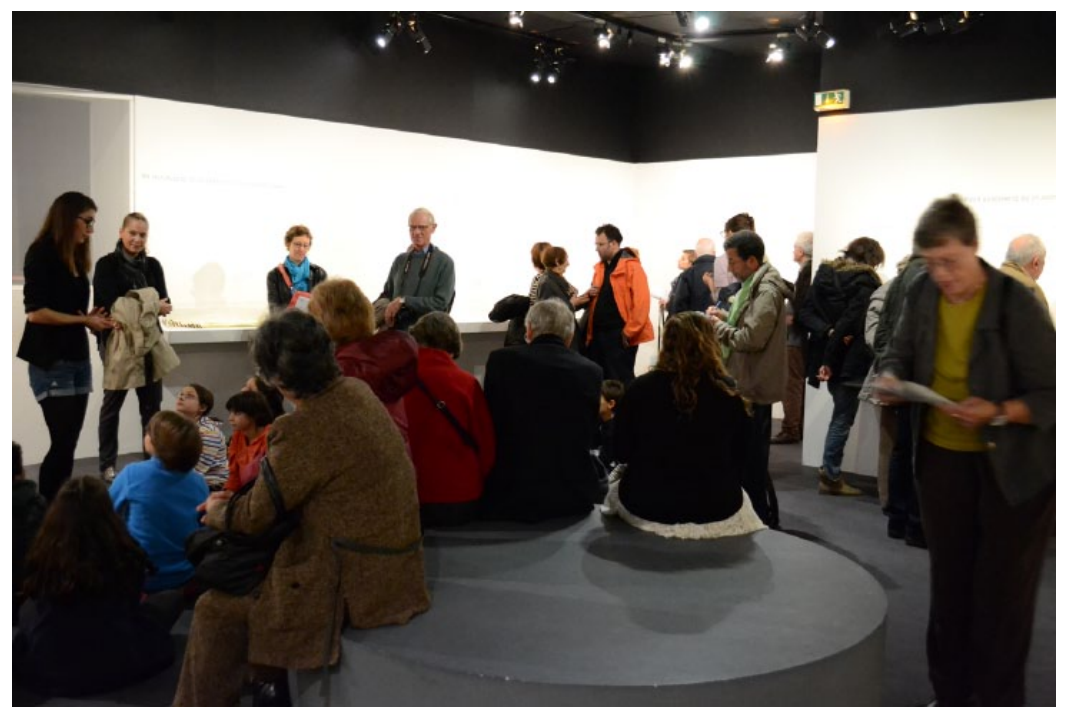

Image 4. A class visiting the exhibition beneath the gaze of numerous visitors, witnessing memory.

\section{From visiting history to witnessing memory}

The normative filter through which the exhibition is seen appears first with particular force in the language norms that run through the visitors' book (Bernard-Donals, 2005). This textual normativity reveals the way in which seeing history is first and foremost the duty to practice 'memory' and 'to remember', as labelled by the visitors. Most of the messages celebrate 'memory', 'its importance for the future' and the 'need to remember'. In this extract, a woman interrupts her visit for a moment to conform herself to the social norm in this matter. She feels 'obliged not to leave':

I'm only at the beginning of the exhibition and I'm already overwhelmed by what I've seen, read ... the unspeakable becomes concrete. All the history books haven't been able to translate what becomes terribly real. The horror. I'll have difficulty getting to the end. But I feel obliged not to leave. We're so far from what I could have imagined, even in my worst nightmares, up until now. Thank you for this reminder, cruel, but necessary for the humanity in every one of us. (Fadila, 9 October 2012)

The normative dimension of the visit is thus clearly visible in the place visitors give to the presence of the school groups in the exhibition. Indeed, the visitor is not so much a witness to history and the visual traces of the past, as to the transmission of this past. The adults, thus, systematically stop their own visits to watch the groups of school children attentively and at some length (Image 4). They thus construct themselves - with satisfaction - as witnesses to the act of 'transmission' that is occurring. During the interviews, the visitors themselves brought up systematically the presence of the 'young people' or 'school groups' within the exhibition, and this in a paradoxical way. The presence of 'noisy', 'numerous' children is first presented as a disturbance, but then, often later in the discussion, it is presented as a source of satisfaction. The expression, taken from one of the interviews, summarises the situation: 'I found it [the exhibition] interesting because there were classes there'.

In another instance, one woman spoke to Louise, who was accompanying a class in the exhibition:

But how old are they? Oh 9 and a half, and 10 years old! My daughter is that age, but I didn't think, I didn't bring her, of course I must come back. ${ }^{9}$ 
The mechanism at work here is not so much a mechanism of transmission - of acquisition of values or knowledge, as one of social validation of the importance of this transmission. The literature on memory, and more specifically on 'post-memory' (Hirsch, 2012), has shown the mechanisms of 'secondary witnessing' (Apel, 2002) and 'witnessing witnessing' (Trezise, 2013). Here, the process is quite different: this is about being a witness to transmission, in other words witnessing memory. Visiting the history of the Holocaust in this case is thus about seeing what we can see, on one hand, and seeing what we have a duty to see, on the other. The exhibition is not so much about what it allows us to see, as what it says we should see. It also tells us that we should see in a particular way and that only some know how to see, or at least that some see better than others.

Indeed, the fieldwork observation of the visits revealed the existence of social roles, in this obligatory participation in transmission. Within a given school group, children with immigrant background, ${ }^{10}$ particularly African or North African, systematically set themselves apart through their particularly active participation in the collective experience of the visit. In private discussion, most of the children told their friends about their indignation in front of the past discrimination they were told about. But of the 10 class visits we observed, the students who participated openly in the discussions with the teacher (and with us) were all children from visible minorities and most often boys - exactly the group that is frequently pointed at, in both French public debate and some of scholarly publications, as being the least inclined to 'integrate' and become 'good citizens'.

Louise asked this class, from the 20th district, for their feedback at the end of the visit. The responses came avidly from two young black boys:

Louise: Why is it important for you to know all this?

Young boy 1(triumphantly, as if he's sure to have found the right answer): So that it never happens again!

Louise: $\quad$ Yes, absolutely.

Young boy 2: If we learn about this, it's also to warn people.

Louise: That's right, now you know what extremes it can go to.

Moreover, at the end of the visit, several of these boys demonstrated their support for civic values via their interest in memory, careful, as any child would be, to see whether their conformity to the expected role had indeed been noticed. This exchange took place between two boys, who happen here too to be black, from a class from the 19th district, after their visit:

Young boy 1: That was so good!

Young boy 2: It was so good, and moving!

Young boy 1: turning to one of us taking observation notes: You can write that it was very good!

Their behaviour seems to suggest that in this specific social situation, more than in others, these children have to see this past, and they owe it to themselves to see it. Again, this observation does not aim to question the 'sincerity' of these boys but simply to highlight the existence of social roles and practices in relation to memory. The social status given to the public expression of concerns about history and memory is sometimes clearly visible in the comments of other visitors who, without being in any way asked to address this issue, spontaneously deplore the lack of 'people from immigrant backgrounds' among the visitors. They often add, with a degree of tension, that of course they (these 'people') don't share 'our history' but that 'it should interest them too'. Yet, in the interviews, these very same visitors, as any other, had previously, and abundantly, referred to the lessons of the exhibition and to 'memory' more broadly, in promoting tolerance, preventing discrimination and transmitting Republican values. 


\section{Conclusion}

Based on the study of the genesis of an exhibition dedicated to the history of the Holocaust in Paris, and of visits to that same exhibition, this article sheds light on the social appropriations of the history of the Holocaust when mediated by objects, photographs, archival material and texts. It demonstrates that these appropriations are less dependent on the artefacts themselves than they are on the social frames in which they take place. Second, it invites scholars in memory and museum studies to pay more attention to this slippage 'from an interpretative project to the symbolics of visitation' (Hughes, 2008: 326). Indeed, this article demonstrates that as a social practice, visits to Holocaust history exhibitions do not mainly lead to a transmission of knowledge of the past, nor of civic values driven from it. A 'transmission' does occur, but it primarily concerns the importance of the transmission itself, and only secondarily concerns the narration of the past in question. While visiting exhibitions on the history of the Holocaust, visitors are primarily looking to witnessing memory at work, so to speak, in observing oneself and others confronting the past. The visits to the exhibition enable the reinforcement of values and knowledge through the visitors' mutual recognition of each other as people sharing common principles and convictions.

This mechanism of witnessing memory states the social status of 'memory' and the civic values attributed to it in contemporary societies. The exhibition's main impact relies on social norms and on this memory as 'commonplace' that pre-exists it.

Finally, this article is based on an empirical case study located in France, and the singularities of this context have up until now been very rarely studied. Consequently, this article calls for more research into this question, based on historical exhibitions in other national and institutional contexts. It shows the need to broaden this approach to other historical periods, using other methodologies, for example, focusing on visitors in contexts other than the visit itself (Anderson and Gosselin, 2008; Falk and Dierking, 1997), as a way to answer one of the questions raised by this article: how does 'memory' became a common reference?

\section{Declaration of Conflicting Interests}

The author(s) declared no potential conflicts of interest with respect to the research, authorship, and/or publication of this article.

\section{Funding}

The author(s) received no financial support for the research, authorship, and/or publication of this article.

\section{Notes}

1. Bagnall (2003), Carnegie (2006), Feldman and Peleikis (2014), Hughes (2008) and Macdonald, (2008)

2. In this respect, it finds an echo in the stimulating work conducted on visits to former concentration and extermination camps (Feldman, 2010; Kugelmass, 2010) or in the school context (Fukuoka, 2011; Oeser, 2010).

3. Sylvain Antichan, Carole Bachelot, Gabrielle Chomentowski, Arnaud Figari and Julie Lavielle. This research received a grant from the research cluster Labex Pasts in Present (ANR-11-LABX-0026-01).

4. Bulletin officiel de l'éducation nationale, 13 December 2012. In French, it says, 'Un référent mémoire et citoyenneté est désignée dans chaque académie'.

5. http://www.memorialdelashoah.org/wp-content/uploads/2016/05/cp_signature_convention_parquet_ lyon_memorial_shoah_19022016.pdf

6. In Paris, the census of the Jews was a key instrument in enabling the arrests to be made.

7. The Drancy Internment Camp is situated in what is now the department of Seine Saint-Denis, in the inner suburbs of Paris. It was the main transit camp for the 76,000 Jews deported from France.

8. It was forbidden to take photos in the exhibition. 
9. Our emphasis.

10. The idea of social role or social frame bears no moral judgement of the people interviewed or observed (Goffman, 1959).

\section{References}

Andermann J and Arnold-de Simine S (2012) Introduction: memory, community and the new museum. Theory, Culture \& Society 29(1): 3-13.

Anderson D and Gosselin V (2008) Private and public memories of Expo 67: a case study of recollections of Montreal's world's fair, 40 years after the event. Museum and Society 6(1): 1-21.

Apel D (2002) Memory Effects: The Holocaust and the Art of Secondary Witnessing. New Brunswick, NJ: Rutgers University Press.

Arnold-de Simine S (2013) Mediating Memory in the Museum: Trauma, Empathy, Nostalgia. Basingstoke: Palgrave Macmillan.

Arnold-de-Simine S (2013) Mediating Memory in the Museum: Trauma, Empathy, Nostalgia. New York: Palgrave.

Bagnall G (2003) Performance and performativity at heritage sites. Museum and Society 1(2): 87-103.

Bernard-Donals MF (2005) Conflations of memory: or, what they saw at the Holocaust museum after 9/11. The New Centennial Review 5(2): 73-106.

Brink C (2000) Secular icons: looking at photographs from Nazi concentration camps. History \& Memory 12(1): 135-150.

Carnegie E (2006) 'It wasn't all bad': representations of working class cultures within social history museums and their impacts on audiences. Museum and Society 4(2): 69-83.

Crane SA (1997) Memory, distortion, and history in the museum. History and Theory 36(4): 44-63.

Credoc (2012) La Visite Des Musées, Des Expositions Et Des Monuments, Etude Pour La Direction Générale Des Patrimoines. Paris: Ministère de la Culture.

Dartt-Newton D (2011) California's sites of conscience: an analysis of the state's historic mission museums. Museum Anthropology 34(2): 97-108.

Davallon J, Gottesdiener H and Poli MS (2000) The 'expert visitor' concept. Museum International 208: $60-64$.

Dekel I (2009) Ways of looking: observation and transformation at the Holocaust memorial, Berlin. Memory Studies 2(1): 71-86.

Eidelman J, Jonchery A and Zizi L (2012) Musées Et Publics: Bilan D’une Décennie (2002-2011). Paris: La Documentation française.

Falk JH and Dierking LD (1997) School field trips: assessing their long-term impact. Curator: The Museum Journal 40(3): 211-218.

Feldman J (2010) Above the Death Pits, beneath the Flag: Youth Voyages to Poland and the Performance of Israeli National Identity. New York: Berghahn Books.

Feldman J and Peleikis A (2014) Performing the hyphen: Engaging German-Jewishness at the Jewish museum Berlin. Anthropological Journal of European Cultures 23(2): 43-59.

Fukuoka K (2011) School history textbooks and historical memories in Japan: a study of reception. International Journal of Politics, Culture, and Society 24(3): 83-103.

Fyfe G and Ross M (1996) Decoding the visitors' gaze. In: Macdonald S and Fyfe G (eds) Theorizing Museums. Oxford: Blackwell, pp. 83-104.

Fyfe G (2006) Sociology and the social aspects of museums. In: Macdonald S (ed.) A Companion to Museum Studies. Oxford: Blackwell, pp. 33-49.

Gensburger S (2015) Witnessing the Robbing of the Jews: A Photographic Album, Paris 1940-1944. Bloomington: Indiana University Press.

Gensburger S (2016a) Halbwachs's studies in collective memory: a founding work for contemporary 'memory studies'? Journal of Classical Sociology 16: 396-413.

Gensburger S (2016b) National Policy, Global Memory: The Commemoration of the 'Righteous' from Jerusalem to Paris 1942-2007. New York: Berghahn Books.

Gensburger S and Dreyfus J-M (2011) Nazi Labour Camps in Paris. New York: Berghahn Books. 
Goffman E (1959) The Presentation of Self in Everyday Life. New York: Anchor.

Herzfeld M (2005) Cultural Intimacy: Social Poetics in the Nation-State. New York: Routledge.

Hirsch M (2012) The Generation of Postmemory: Writing and Visual Culture after the Holocaust. New York: Columbia University Press.

Hoskins A (2003) Signs of the Holocaust: exhibiting memory in a mediated age. Media, Culture \& Society 25(1): 7-22.

Hughes R (2008) Dutiful tourism: encountering the Cambodian genocide. Asia Pacific Viewpoint 49(3): $318-330$.

Huistra P, Molema M and Wirt D (2014) Political values in a European museum. Journal of Contemporary European Research 10(1): 124-136.

Jones S (2010) Negotiating authentic objects and authentic selves: beyond the deconstruction of authenticity. Journal of Material Culture 15(2): 181-203.

Jonsson H (2012) Manikin-ship: value-added relatedness in Vietnamese museums, 1996-2005. The Australian Journal of Anthropology 23: 212-228.

Kansteiner W (2002) Finding meaning in memory: a methodological critique of collective memory studies. History and Theory 41(2): 179-197.

Kugelmass J (2010) Rites of the tribe: the meaning of Poland for American Jewish visitors. In: Gmelch S (ed.) Tourists and Tourism: A Reader. Long Grove, IL: Waveland Press, pp. 369-396.

Lawrence G (1991) Rats, street gangs, and culture: evaluation in museums. In: Kavanagh G (ed.) Museum Languages: Objects and Text. Leicester: Leicester University Press, pp. 9-32.

Levy D and Sznaider N (2002) The Holocaust and the formation of cosmopolitan memory. European Journal of Social Theory 5(1): 87-106.

Levy D and Sznaider N (2010) Human Rights and Memory. University Park, PA: Pennsylvania State University Press.

Lisle D (2006) Sublime lessons: education and ambivalence in war exhibitions. Millennium : Journal of International Studies 34(3): 841-862.

Macdonald S (2002) Behind the Scenes at the Science Museum. London: Bloomsbury Academic.

Macdonald S (2008) Difficult Heritage: Negotiating the Nazi past in Nuremberg and beyond. London: Routledge.

Macdonald S (2013) Memorylands: Heritage and Identity in Europe Today. London: Routledge.

McRainey DL and Russick J (eds) (2010) Connecting Kids to with History with Museum Exhibitions. Walnut Creek, CA: Left Coast Press.

Mance J and Savoie H (2011) De l'influence d'une visite au musée sur la conscience historique des élèves du primaire. Canadian Journal of Social Research 4: 42-72.

Meyers PA (2002) The Holocaust in American life. European Journal of Social Theory 5: 149-164.

Oeser A (2010) Enseigner Hitler: Les Adolescents Face Au Passé Nazi En Allemagne. Paris: Maison des Sciences de l'Homme.

Popov A and Deák D (2015) Making sense of the 'difficult' past: transmission of political heritage and memory-work among young people across Europe. The Sociological Review 63(2): 36-52.

Thomas JA (2009) The evidence of sight. History and Theory 48(4): 151-168.

Trezise T (2013) Witnessing Witnessing: On the Reception of Holocaust Survivor Testimony. New York: Fordham University Press.

Urry J (2002) The Tourist Gaze. London: SAGE.

Violi P (2012) Trauma site museums and politics of memory: Tuol Sleng, Villa Grimaldi and the Bologna Ustica museum. Theory, Culture \& Society 29(1): 36-75.

Williams P (2007) Memorial Museums: The Global Rush to Commemorate Atrocities. Oxford: Berg Publishers.

\section{Author biography}

Sarah Gensburger is a Sociologist and a Political Scientist of memory. She is currently a researcher in social sciences at the French National Center for Scientific Research (CNRS). She just published National Policy, Global Memory: The Commemoration of the 'Righteous' from Jerusalem to Paris, 1942-2007 (Berghahn Books, 2016) and Mémoire vive. Chroniques d'un quartier. Bataclan 2015-2016 (Anamosa, 2017). 